\title{
INFLUENCE OF SOWING DATES ON THE PHENOLOGICAL DEVELOPMENT, GROWTH AND YIELD OF WHITE MAIZE GENOTYPES
}

\author{
S. Akhtar1 ${ }^{1}$, M.J. Ullah ${ }^{2}$, A. Hamid ${ }^{3}$, M.S. Islam ${ }^{2}$, M.K.U. Ahamed ${ }^{4}$ and S.M. Masum ${ }^{2}$ \\ ${ }^{1}$ Krishi Gobeshona Foundation, ${ }^{2}$ Department of Agronomy, ${ }^{4}$ Department of Botany, Sher-e-Bangla Agricultural \\ University, ${ }^{3}$ Department of Agronomy, Bangabandhu Sheikh Mujibur Rahman Agricultural University \\ Corresponding E-mail: shahrina.akhtar@gmail.com
}

(Received: 05 March 2021, Accepted: 14 March 2021)

Keywords: White maize, genotypes, sowing date, phenology, performance

\begin{abstract}
The experiment was conducted at the Sher-e-Bangla Agricultural University $\left(90^{\circ} 22\right.$ E, $23^{\circ} 41 \mathrm{~N}$ ), Dhaka, Bangladesh in Rabi (winter) season of 2017-2018 to study the effects of sowing date on growth and yield of four white maize genotypes, viz. PSC-121, Yangnuo-7, Yungnuo-30 and Changnuo-6. Sowing dates were November 26, December 11, and December 26. Data were collected on different phenological growth stages, dry matter, physiological attributes, yield, and yield attributes. A delay in sowing date delayed the time required for seedling emergence, to reach the 6-leaf collar, maturity stage, and also reduced yield. The planting of PSC-121 in November 26 gave the highest dry matter plant ${ }^{-1}$, the number of grains $\mathrm{cob}^{-1}$, and 100- grain weight that resulted in the highest grain yield (11.65 t/ha) of the genotype.
\end{abstract}

\section{Introduction}

In Bangladesh, maize covers an area of about $0.304 \mathrm{M}$ ha with a production of over $2 \mathrm{MT}$ per year which is almost exclusively used as livestock feed. However, white maize covers only $12 \%$ of worldwide which is regularly grown for providing grains for human ingestion (Ullah et al., 2017). The interest of consumers is increasing, in white maize particularly in those regions where maize is the main cereal for food. Preferences for endosperm color depend on the local traditions, though white is generally chosen for human food. Today, white maize is preferred for human consumption because the degradation of carotenoids during baking or frying causes a strong aroma and flavor (Malver et al., 2008). Maize can be grown all over the country. It is a fast-growing crop that grows well with a minimum temperature of $10^{\circ} \mathrm{C}$ and a maximum of $30^{\circ} \mathrm{C}$. However, a significant decrease in maize yield with delayed sowing was reported by Anapalli et al. (2005) and Williams II (2008). Identification of suitable high-yielding varieties (HYV) and optimum seeding time are the two key important factors for sustainable maize production (Ramankutty, 2002; Liaqat et al., 2018). The phenology of corn has been described as the appearance of leaves or leaf collars during the vegetative stage and the accumulation of material in the grain during the reproductive stage. The duration of phenological events changes based on accumulated temperature patterns which are depended on prevailing air temperature. As the relationship between various physical factors of the environment and seasonal changes dictates the phenology of a plant during its life cycle (Varma et al., 2014). Its adaptation varies in terms of the ability to mature and setting grains. Sowing at proper time and selection of good variety are the most important factors for cropping system. To minimize the negative effect of 
some abiotic and biotic stress on the plant, sowing date can play a major role in determining the seed yield, quality, seed germination, and understanding whole phenology stages in many regions (Koca and Canavar, 2014). In Bangladesh conditions, maize planted in the late dry season suffers from heat stress during flowering and early grain filling stages which may affect these developmental stages. Sometimes drought coupled with heat shock may also affect the crop. Since climate change impacts are visible in Bangladesh agriculture, it is necessary to look for cereal germplasms that can withstand high temperatures. Evaluation of new maize germplasms in terms of adaptive potential under high heat regimes as well as under optimal conditions could open up an avenue for sustaining maize production in Bangladesh. It is also necessary to identify the morphological and physiological traits to heat stress of maize genotypes with sowing date.

\section{Materials and Methods}

The experiment was conducted in the experimental field of Sher-e-Bangla Agricultural University, Dhaka-1207, during the rabi season of 2017-2018. The soil was Shallow Red Brown Terrace that belongs to the Tejgaon soil series under the Agro-ecological Zone AEZ-28), Madhupur Tract (Rashid et al., 2018). The experimental area was situated at $23^{\circ} 41 \mathrm{~N}$ latitude and $90^{\circ} 22 \mathrm{E}$ longitude at an elvation of 8.6 meters above sea level (Khanam et al., 2016). The average sunshine hours and temperature during the study period are presented in Fig. 1 . The experiment comprised two factors; varieties: $V_{1}=$ PSC $121, V_{2}=$ Yangnuo-7, $V_{3}=$ Youngnau30 and $\mathrm{V}_{4}=$ Changnuo-6; and sowing date: $\mathrm{S}_{1}=$ November 26, $\mathrm{S}_{2}=$ December 11 and $\mathrm{S}_{3}=$ December 26, 2017. The experiment was laid out in a Randomized Complete Block Design (RCBD) with three replications. Unit plot size was $2.4 \mathrm{~m} \times 3.5 \mathrm{~m}$. The amount of fertilizer in the form of urea, triple super phosphate (TSP), muriate of potash (MoP), gypsum, zinc sulphate, and boric acid was calculated according to BARI (2016). The total amount of TSP, MoP, gypsum, zinc sulphate, and boric acid and 1/3rd of total urea were broadcasted and incorporated in a plot two days before sowing. The rest of the urea was top-dressed in two equal installments: One at 4-6 leaf stage and another at 10-12 leaf stage (pre-tasseling stage). Cow dung was applied @ 5 ton/ha at the time of final land preparation. Seeds of white maize genotypes were sown in a line $60 \mathrm{~cm} \times 20 \mathrm{~cm}$ apart. Different intercultural operations such as thinning, weeding, watering, earthing up, etc. were done when necessary. Phenological, growth, and yield data were measured. The collected data were analyzed, and the mean differences were compared by least significant difference (LSD) using a computer-operated program Statistix 10.
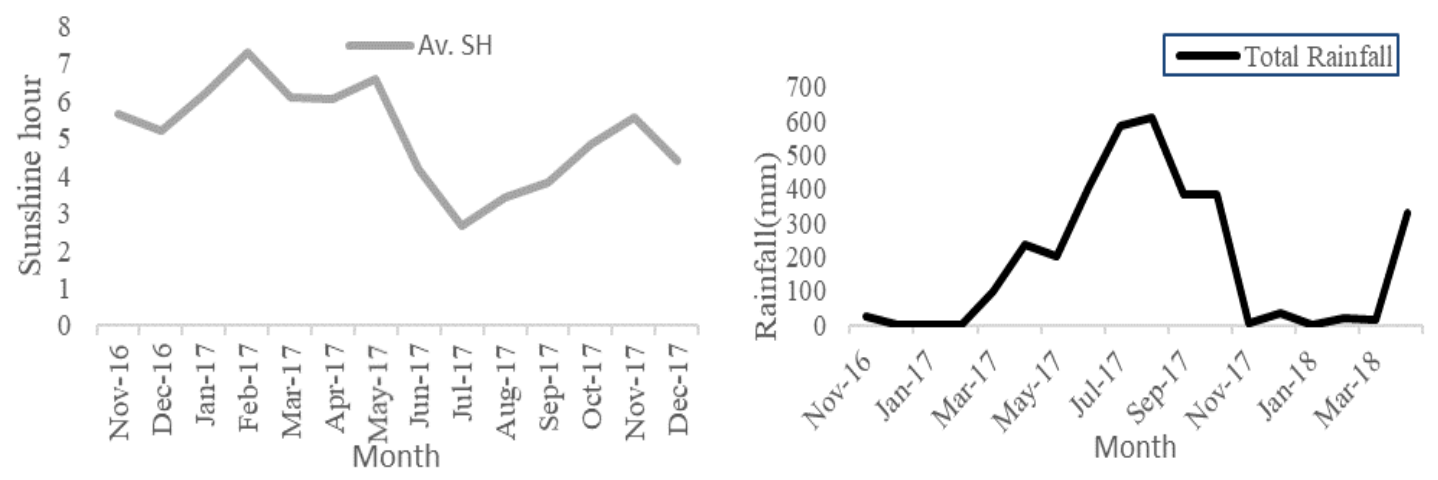

Fig. 1. Line graphs showing the average sunshine hour (A) and total rainfall (B) from November 16 to April 18, 2017 in the study area 


\section{Results and Discussion}

\section{Days to emergence}

Corn emergence (VE stage) is achieved when the coleoptiles reach and break through the soil surface. Generally, corn that emerges under favorable conditions can be 4 to 5 days after sowing. The date of emergence is the function of germination time. The genotype and sowing dates and their interactions had a significant effect (Figs. 2-4) on days to emergence. The maximum date of emergence was found from Changnuo-6 (6 days) which was statistically similar to Yungnuo-7 (6 days), and whereas the lowest date of emergence from PSC-121 (5 days). Crop sown on December 11 recorded the maximum date of emergence which was statistically at par with November 26 sowing. The lowest date of emergence ( 5 days) was observed from November 26. Among the interaction effect, the highest date of emergence was observed from the combination of December 11 sowing with genotype Changnuo-6 (6 days), while the lowest date of emergence from November 25 sowing with Yungnuo-30 (5 days). The maximum date of emergence under the December 11 sowing was attributed to the maximum date of emergence characters. Ali et al. (2018) reported that one of the most vital factors contributing to the yield gap is the sowing of maize on appropriate sowing dates. The delay in sowing date can lead to a linear decrease in grain yields (Anapalli et al., 2005).

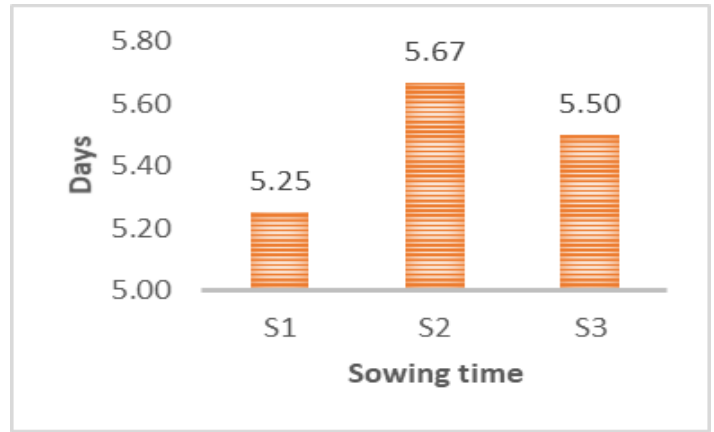

Fig. 2. Days to emergence of white maize as influenced by varying sowing dates $\left(\mathrm{S}_{1}=26\right.$ November 2017, 11th December 2017 and 26th December 2017); (LSD5\% =0.09)

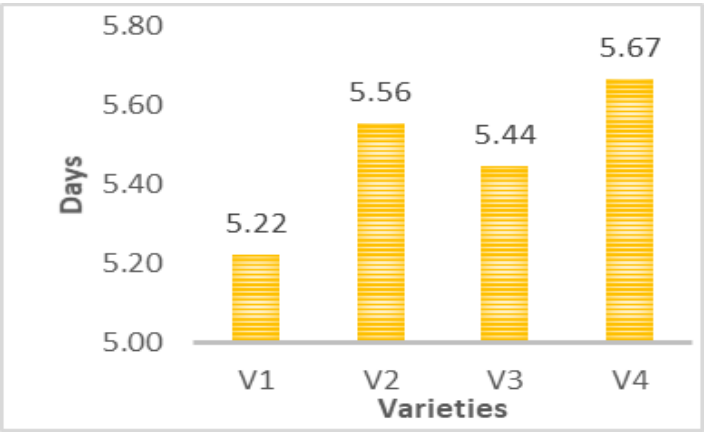

Fig. 3. Days to emergence of different white maize genotypes $\left(\mathrm{V}_{1}=\mathrm{PSC}-121, \mathrm{~V}_{2}\right.$ =Yangnuo-7, $\mathrm{V}_{3}=$ Yungnuo- $30, \mathrm{~V}_{4}=$ Changnuo-6; LSD5\% $=0.11$ )

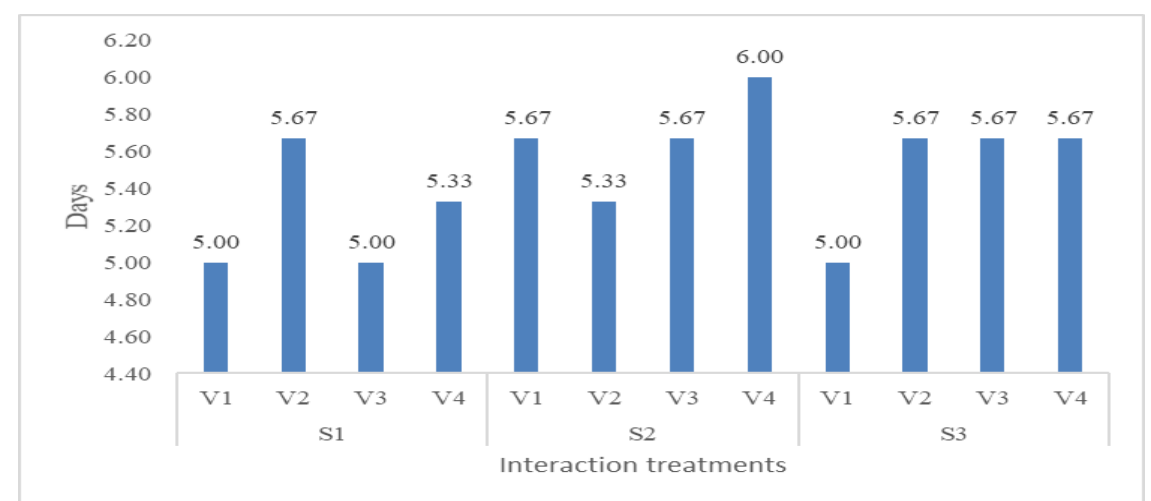

Fig. 4. Days to emergence of white maize as influenced by varying sowing dates and genotypes $\left(\mathrm{V}_{1}=\right.$ PSC-121, $\mathrm{V}_{2}=$ Yangnuo-7, $\quad \mathrm{V}_{3}=$ Yungnuo-30, $\mathrm{V}_{4}=$ Changnuo-6; $\mathrm{S}_{1}=26$ th November, $S_{2}=11$ th December and $S_{3}=26$ th December; LSD5\% $=0.19$ ). 


\section{Days to 6-collar leaf stage (V6)}

Data on the 6-collar leaf stage have been presented in Figs. 5-7 and the variety, sowing dates, and their interactions had a significant effect. During this stage, the uppermost ear and tassel were initiated and kernel row numbers were determined. The highest (42.44 days) date to the 6collar leaf stage was found from PSC-121 and the lowest (32.11 days) from Yungnuo-7. Crop sown on December 26 recorded the maximum (40 days) date to 6-collar leaf stage which was statistically at par with May 29 sowing (19 days). The lowest 6-collar leaf (36 days) was observed from July 6 . Among the interaction effect of white maize varieties and sowing dates the highest days to 6-collar leaf stage (42. days) from the combination of PSC-121 with December 26 sowing. The lowest date to 6-collar leaf stage (30 days) was obtained from the treatment combination Yungnuo-7 with November 26 sowing.

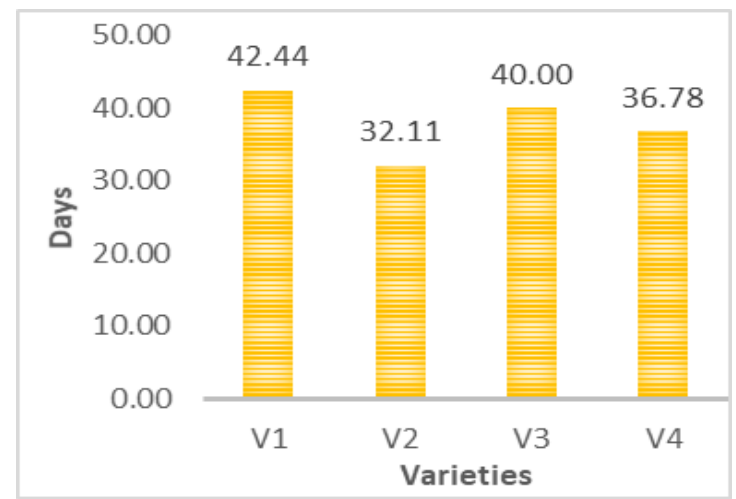

Fig. 5. Days to 6-collar leaf stage of different white maize genotypes grown across varying sowing dates $\left(\mathrm{V}_{1}=\mathrm{PSC}-121\right.$, $\mathrm{V}_{2}=$ Yangnuo-7, $\mathrm{V}_{3}=$ Yungnuo-30, $\mathrm{V}_{4}=$ Changnuo-6; LSD5\% $=0.11$ ).

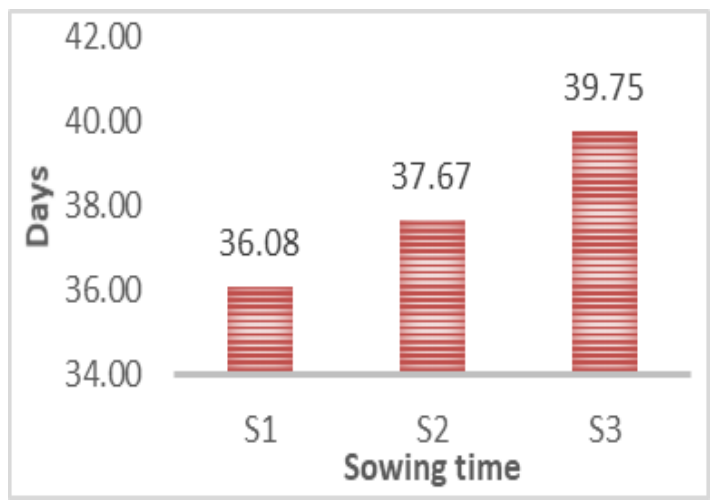

Fig. 6. Days to 6-collar leaf stage of white maize as influenced by varying sowing dates $\left(26\right.$ November 2017, $11^{\text {th }}$ December 2017 and 26th December 2017) $(\mathrm{LSD} 5 \%=0.09)$.

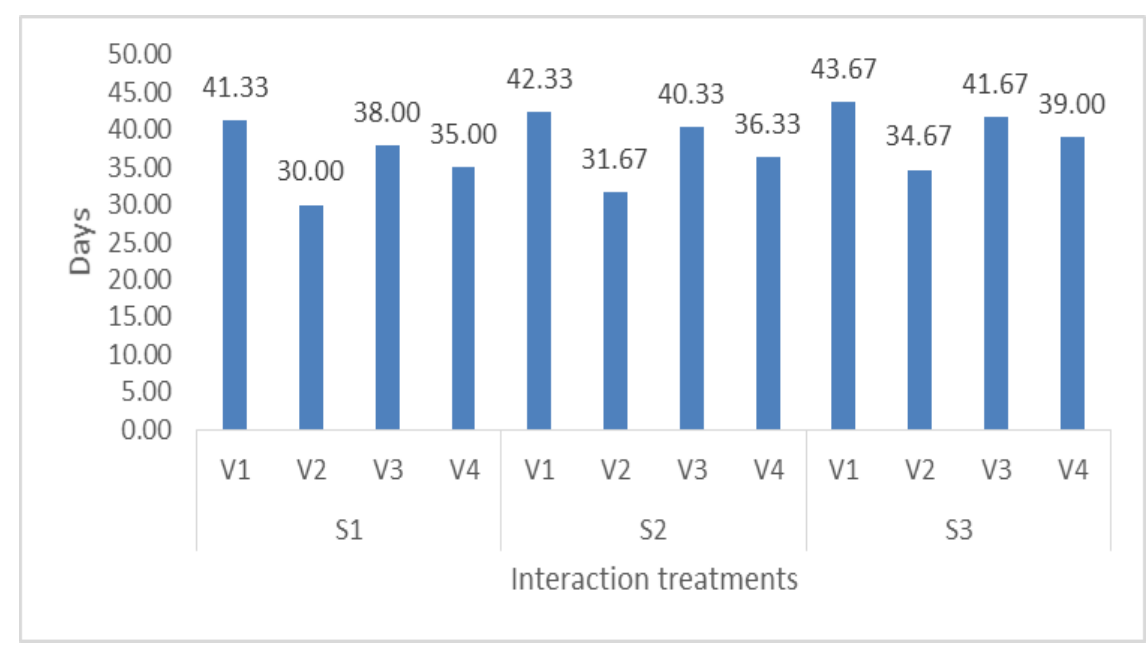

Fig. 7. Days to 6-collar leaf stage of white maize grown season as influenced by varying sowing dates and genotypes ( $\mathrm{V}_{1}=$ PSC-121, $\mathrm{V}_{2}=$ Yangnuo-7, $\mathrm{V}_{3}=$ Yungnuo- $30, \mathrm{~V}_{4}=$ Changnuo6; $S_{1}=26$ th November $S_{2}=11$ th December and $S_{3}=26$ th December; LSD5\% $=0.19$ ). 


\section{Days to 10-collar leaf stage (V10)}

During the $\mathrm{V}_{10}$ growth stages, any management practice that helps reduce plant stress and allows for adequate nutrient levels can help maximize yield potential. Ten leaves have formed, the corn stalk elongates, and the tassel rapidly grows during this phase. The variety, sowing dates, and their interactions had a significant effect on days to 10-collar leaf stage (Figs. 8-10). The maximum (62 days) date to 10-collar leaf stage was found from Yungnuo-30, which was statistically similar to PSC-121 (62 days), and the lowest (52. days) date 10-collar leaf was found from Yungnuo-7. Crop sown on December 26 recorded the highest (59 days) date to 10-collar leaf stage. The lowest (57 days) date to the 10-collar leaf stage was observed from November 26. Among the interaction, the highest date to 10-collar leaf stage (63 days) was observed from the combination of PSC-121 genotype with December 26 sowing. While the lowest (51 days) date to 10-collar leaf stage was obtained from the treatment combination of Yungnuo-7 variety with November 26 sowing.

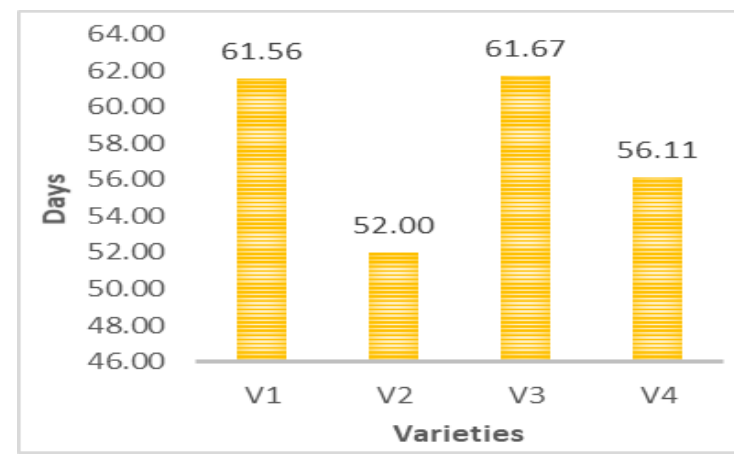

Fig. 8. Days to 10-collar leaf stage of different white maize genotypes ( $\mathrm{V}_{1}=\mathrm{PSC}-121$, $\mathrm{V}_{2}=$ Yangnuo-7, $\quad \mathrm{V}_{3}=$ Yungnuo-30, $\mathrm{V}_{4}=$ Changnuo-6; LSD5 $\%=0.9$ ).

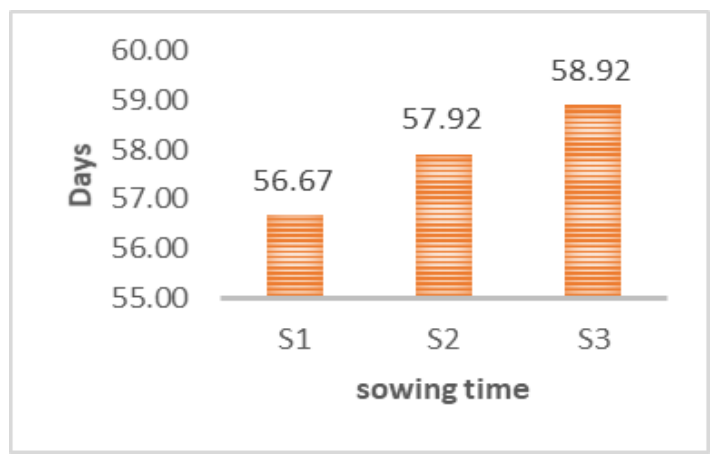

Fig. 9. Days to 10-collar leaf stage of white maize as influenced by varying sowing dates $\left(S_{1}=26\right.$ November, $S_{2}=11$ th December and $S_{3}=26$ th December (LSD5\% =0.8).

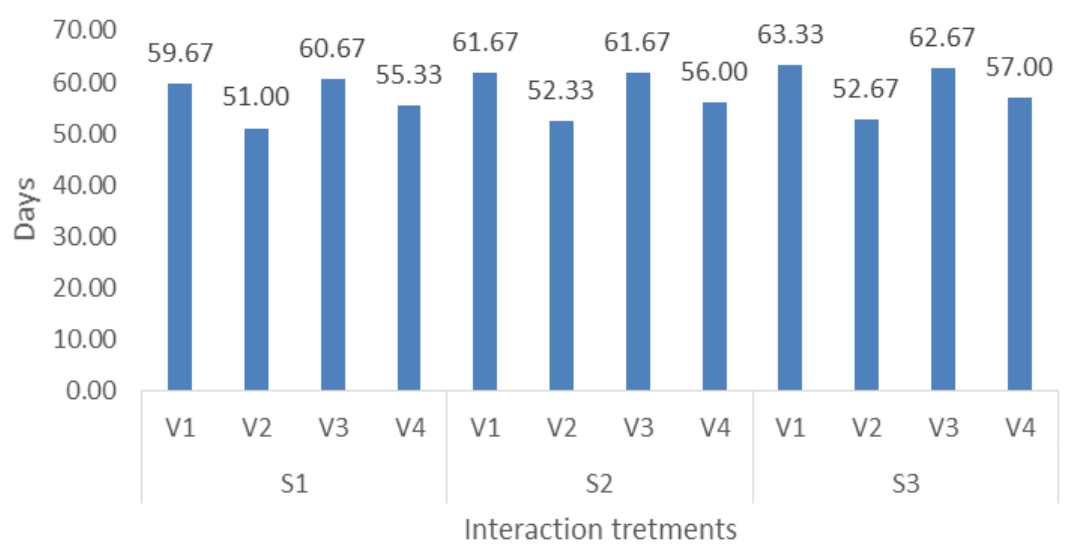

Fig. 10. Days to 10-collar leaf stage of white maize grown as influenced by varying sowing dates and genotypes $\left(\mathrm{V}_{1}=\mathrm{PSC}-121, \mathrm{~V}_{2}=\right.$ Yangnuo-7, $\mathrm{V}_{3}=$ Yungnuo-30, $\mathrm{V}_{4}=$ Changnuo- 6 ; $\mathrm{S}_{1}=26$ th, $\mathrm{S}_{2}=11$ th December and $\mathrm{S}_{3}=26$ th December ; LSD5\% $=0.16$ ). 


\section{Days to 12-collar leaf stage (V12)}

At $\mathrm{V}_{12}$, kernel row determination is almost complete. As the plant nears pollination, soil moisture and nutrient availability become increasingly critical for yield determination. The genotype, sowing dates, and their interactions had a significant effect on days to 12-collar leaf stage (Figs. 11-13). The maximum (64 days) date to 12-collar leaf stage was found from Yungnuo-30, which was statistically similar to Yungnuo-30 (62.44 days) and the lowest (53.89 days) date of emergence from Yungnuo-7. Crop sown on December 26 recorded the highest (61 days) date to the 12-collar leaf stage. The lowest date of emergence (58 days) was observed from November 26. Among the interaction, genotypes and sowing dates, the highest date to 12-collar leaf stage (65 days) was observed from the combination of genotype Yungnuo-30 with December 26 sowing. While the lowest (53 days) date to the 12-collar leaf stage was obtained from the treatment combination of genotype Yungnuo-7 with November 26 sowing.

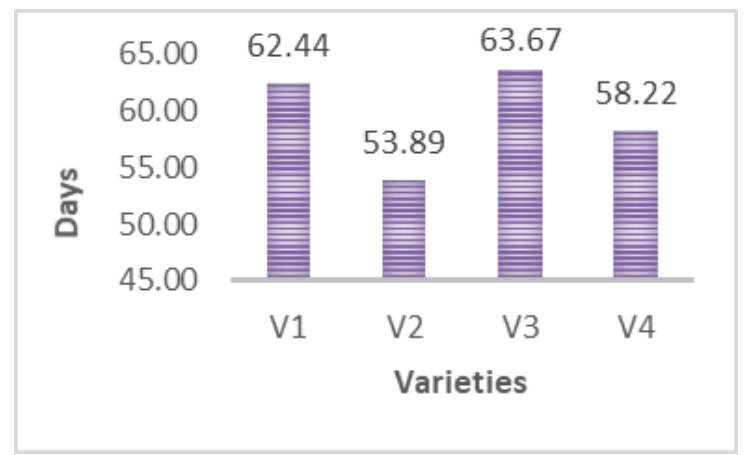

Fig. 11. Days to 12 -collar leaf stage of different white maize genotypes $\left(\mathrm{V}_{1}=\mathrm{PSC}-121\right.$, $\mathrm{V}_{2}=$ Yangnuo- $7, \quad \mathrm{~V}_{3}=$ Yungnuo-30, $\mathrm{V}_{4}=$ Changnuo-6; LSD5\%=0.9).

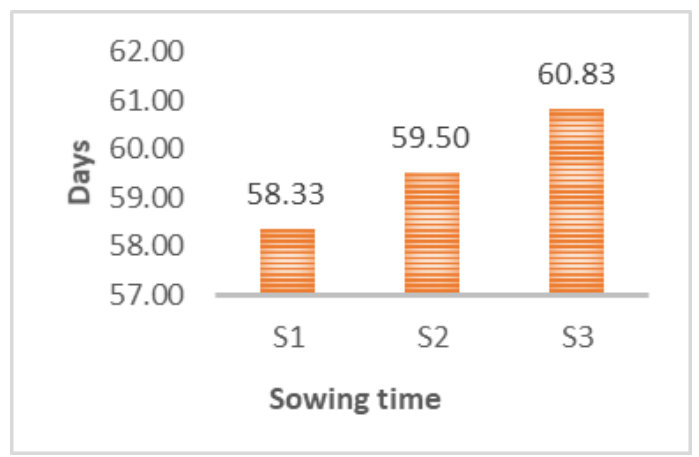

Fig. 12. Days to 12-collar leaf stage of white maize as influenced by varying sowing dates $\left(\mathrm{S}_{1}=26\right.$ November, 11th December and 26th December) $(\mathrm{LSD5} \%=0.8)$.

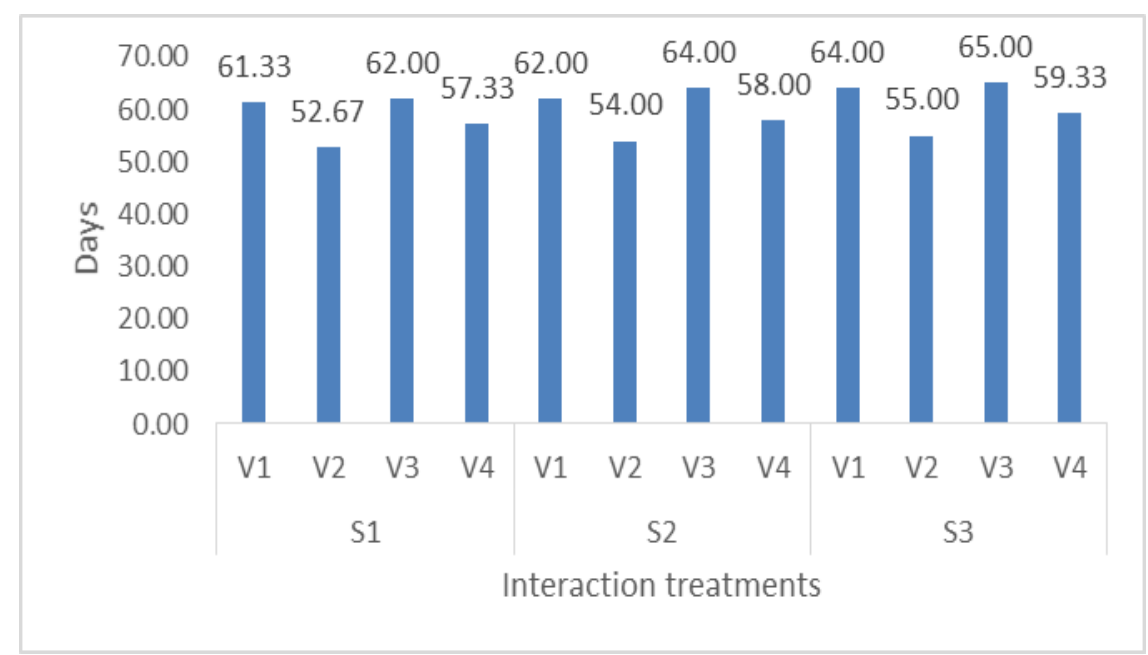

Fig. 13. Days to 12-collar leaf stage of white maize grown as influenced by varying sowing dates and genotypes $\left(\mathrm{V}_{1}=\mathrm{PSC}-121, \mathrm{~V}_{2}=\right.$ Yangnuo- $7, \mathrm{~V}_{3}=$ Yungnuo- $30, \mathrm{~V}_{4}=$ Changnuo- 6 ; $S_{1}=26$ th November, $S_{2}=11$ th December and $S_{2}=26$ th December; LSD5\% $=0.16$ ). 


\section{Plant height}

The variety, sowing dates, and their interactions had a significant effect on plant height in Figs. 14-16. The highest plant height $(203.47 \mathrm{~cm})$ was found from PSC-121 and the lowest $(158.02$ $\mathrm{cm}$ ) from Yungnuo-7. Crop sown on November 26 was recorded the highest plant height $(201.03 \mathrm{~cm})$. The lowest plant height (158.25 days) was observed from December 26. Among the interaction, the highest plant height $(217.67 \mathrm{~cm})$ was observed from the combination of PSC-121 with November 26 sowing while the lowest date of plant height $(137.33 \mathrm{~cm})$ from the treatment combination of genotype Yungnuo-7 with December 26 sowing.

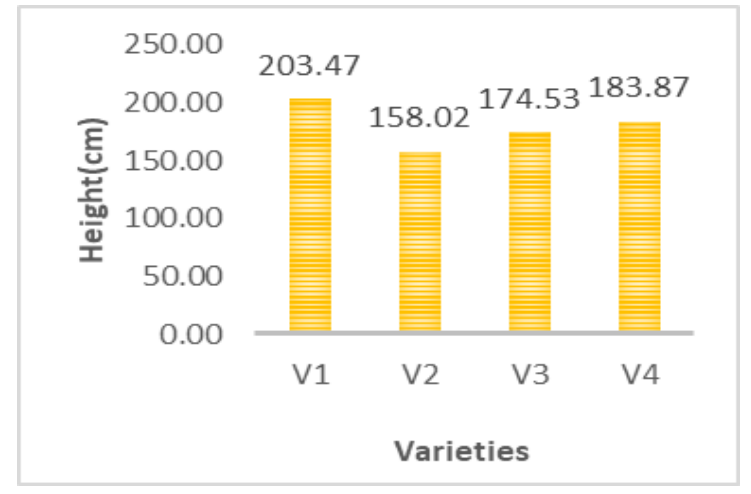

Fig. 14. Plant height of different white maize genotypes $\left(\mathrm{V}_{1}=\mathrm{PSC}-121, \quad \mathrm{~V}_{2}=\right.$ Yangnuo-7, $\mathrm{V}_{3}=$ Yungnuo-30, $\mathrm{V}_{4}=$ Changnuo-6; LSD5\% 0.09 grown in Rabi 2017-2018 season.

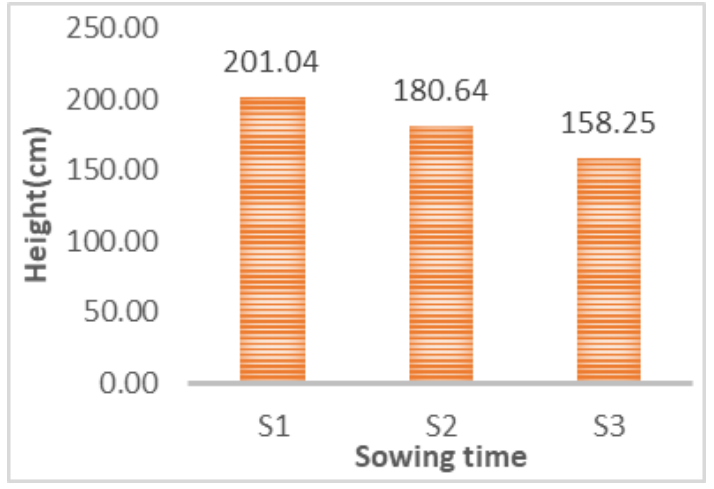

Fig. 15. Plant height of white maize as influenced by varying sowing dates $\left(\mathrm{S}_{1}=26 \quad\right.$ November, $\mathrm{S}_{2}=11$ December and $\mathrm{S}_{3}=26$ December) (LSD5\% $=0.08)$.

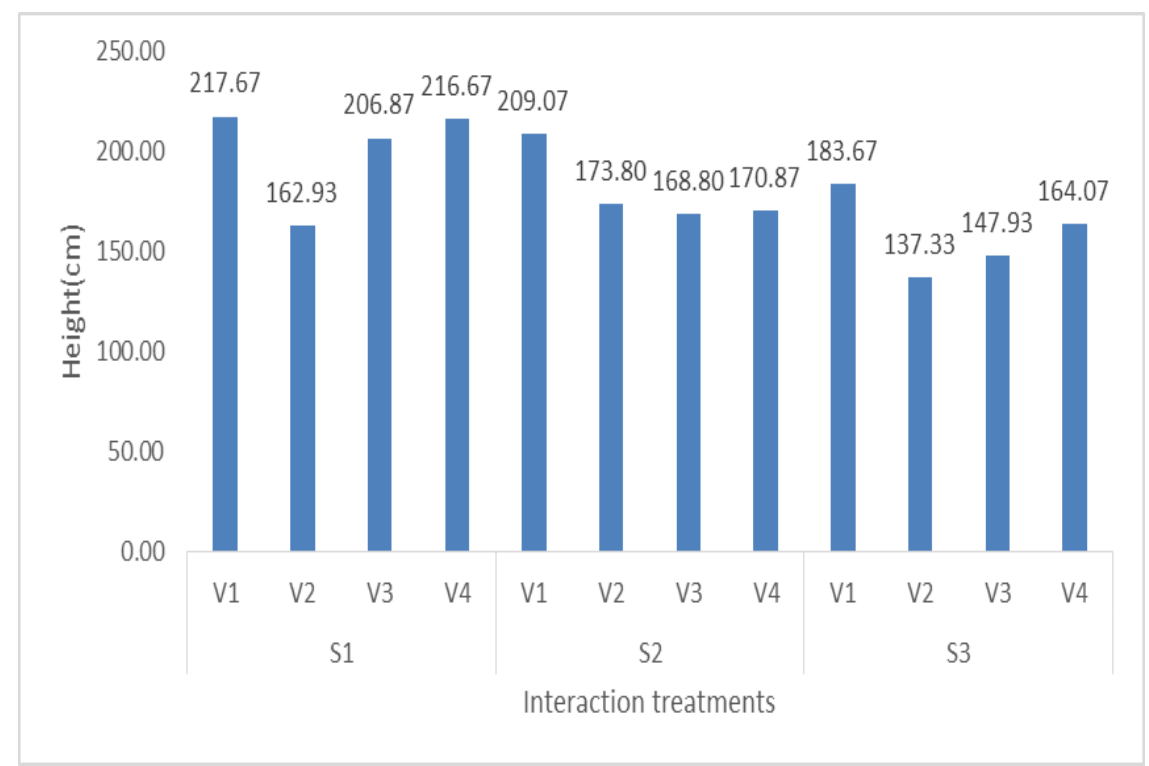

Fig. 16. Plant height of white maize as influenced by varying sowing dates and genotypes $\left(\mathrm{V}_{1}=\mathrm{PSC}-121, \mathrm{~V}_{2}=\right.$ Yangnuo-7, $\mathrm{V}_{3}=$ Yungnuo-30, $\mathrm{V}_{4}=$ Changnuo-6; $\mathrm{S}_{1}=26$ th November, $\mathrm{S}_{2}=11$ th December and $\mathrm{S}_{3}=26$ th December; LSD5\% $=017$ ). 


\section{Leaf area per plant}

Leaf area per plant varied depending upon the growth stages, the smallest $\left(0.0177-0.0341 \mathrm{~m}^{2}\right.$ at 30 DAS while the greatest $\left(0.6763-0.7600 \mathrm{~m}^{2}\right)$ at maturity (Table 1$)$ with the advancement of plant age the leaf area of the individual plant progressively increased. At the earlier stages, the leaf area of the treatments was inconsistent while at the later stages the effect of the treatments was found to be conspicuous. At the maturity, the leaf area in most of the cases was found to be greater with the Changnuo- 1 which at the latest stage ranged 0.6843-0.7536. The leaf area in most of the cases was found to be greater with the second sowing which at the latest stage ranged from 0.7172-0.7214. It was the greatest with the latest sowing at 90 DAS (days after sowing) at which it ranged from $0.8035-0.8229$. At the maturity, the leaf area in most of the cases was found to be greater with the interaction effect of Changnuo-1 and December 26 and at this stage, the leaf area per plant ranged $0.6841-0.7600 \mathrm{~m}^{2}$.

Table 1. Leaf area per plant of white maize grown in Rabi 2017-18 season as influenced by genotypes and varying sowing dates

\begin{tabular}{|c|c|c|c|c|c|c|}
\hline \multirow{2}{*}{ Treatments } & \multicolumn{6}{|c|}{ Leaf area plant ${ }^{-1}\left(\mathrm{~m}^{2}\right)$ at different days after sowing } \\
\hline & 30 DAS & 45 DAS & 60 DAS & 75 DAS & 90 DAS & At harvest \\
\hline \multicolumn{7}{|c|}{ Effect on variety } \\
\hline $\mathrm{V}_{1}$ & 0.0194 & 0.0324 & 0.1789 & 0.3469 & 0.8391 & 0.7113 \\
\hline $\mathrm{V}_{2}$ & 0.0235 & 0.0422 & 0.2607 & 0.4989 & 0.7580 & 0.6843 \\
\hline $\mathrm{V}_{3}$ & 0.0246 & 0.0399 & 0.2277 & 0.4915 & 0.8690 & 0.7536 \\
\hline $\mathrm{V}_{4}$ & 0.0248 & 0.0373 & 0.2091 & 0.4315 & 0.7770 & 0.7286 \\
\hline $\mathrm{LSD}_{5 \%}$ & 1.60 & 0.03 & 0.30 & 0.10 & 0.08 & 0.09 \\
\hline \multicolumn{7}{|c|}{ Effect on sowing dates } \\
\hline$S_{1}$ & 0.0216 & 0.0406 & 0.2103 & 0.4311 & 0.8061 & 0.7172 \\
\hline $\mathrm{S}_{2}$ & 0.0233 & 0.0372 & 0.2259 & 0.4095 & 0.8035 & 0.7198 \\
\hline $\mathrm{S}_{3}$ & 0.0243 & 0.0361 & 0.2210 & 0.4861 & 0.8229 & 0.7214 \\
\hline $\mathrm{LSD}_{5 \%}$ & 1.39 & 0.03 & 0.26 & 0.08 & 0.08 & 0.07 \\
\hline \multicolumn{7}{|c|}{ Interaction effect of variety and sowing date } \\
\hline $\mathrm{V}_{1} \mathrm{~S}_{1}$ & 0.0161 & 0.0298 & 0.1502 & 0.3147 & 0.8576 & 0.7068 \\
\hline $\mathrm{V}_{1} \mathrm{~S}_{2}$ & 0.0206 & 0.0375 & 0.1911 & 0.3481 & 0.7956 & 0.7083 \\
\hline $\mathrm{V}_{1} \mathrm{~S}_{3}$ & 0.0216 & 0.0299 & 0.1953 & 0.3780 & 0.8642 & 0.7187 \\
\hline $\mathrm{V}_{2} \mathrm{~S}_{1}$ & 0.0263 & 0.0507 & 0.2787 & 0.5290 & 0.7334 & 0.6841 \\
\hline $\mathrm{V}_{2} \mathrm{~S}_{2}$ & 0.0181 & 0.0374 & 0.2048 & 0.4064 & 0.7660 & 0.6926 \\
\hline $\mathrm{V}_{2} \mathrm{~S}_{3}$ & 0.0262 & 0.0387 & 0.2986 & 0.5614 & 0.7747 & 0.6763 \\
\hline $\mathrm{V}_{3} \mathrm{~S}_{1}$ & 0.0219 & 0.0459 & 0.2041 & 0.5292 & 0.8725 & 0.7481 \\
\hline $\mathrm{V}_{3} \mathrm{~S}_{2}$ & 0.0341 & 0.0420 & 0.3136 & 0.4778 & 0.8670 & 0.7528 \\
\hline $\mathrm{V}_{3} \mathrm{~S}_{3}$ & 0.0177 & 0.0318 & 0.1654 & 0.4676 & 0.8677 & 0.7600 \\
\hline $\mathrm{V}_{4} \mathrm{~S}_{1}$ & 0.0222 & 0.0360 & 0.2083 & 0.3515 & 0.7607 & 0.7297 \\
\hline $\mathrm{V}_{4} \mathrm{~S}_{2}$ & 0.0206 & 0.0319 & 0.1940 & 0.4057 & 0.7853 & 0.7253 \\
\hline $\mathrm{V}_{4} \mathrm{~S}_{3}$ & 0.0317 & 0.0441 & 0.2249 & 0.5373 & 0.7851 & 0.7307 \\
\hline $\operatorname{LSD}_{(0.05)}$ & 0.078 & 0.06 & 0.52 & 0.17 & 0.15 & 0.15 \\
\hline CV $(\%)$ & 18.4 & 15.29 & 19.82 & 3.47 & 1.68 & 1.93 \\
\hline
\end{tabular}

Note: $\left(\mathrm{V}_{1}=\mathrm{PSC}-121, \mathrm{~V}_{2}=\right.$ Yangnuo-7, $\mathrm{V}_{3}=$ Yungnuo-30, $\mathrm{V}_{4}=$ Changnuo-6; $\mathrm{S}_{1}=26^{\text {th }}$ November, $\mathrm{S}_{2}=11$ th December and $\mathrm{S}_{3}=26$ th December 


\section{Stover dry weight per plant from 30 to 90 DAS}

Dry weight per plant increased progressively with advances of growth stages from 30 days after sowing up to maturity. At 30 DAS each plant accumulated dry weight at around $20 \mathrm{~g}$ in the season. The dry weight gradually increased and attained 79-80 g at 75 (almost flowering) and then finally reached around $120.26 \mathrm{~g}$ at maturity. It was apparent that the dry weight was somewhat inconsistent with sowing dates.

Table 2. Dry weight per plant at different growth stages of white maize genotypes under varying sowing dates during Rabi 2017-18 up to 90 DAS

\begin{tabular}{|c|c|c|c|c|c|}
\hline \multirow{2}{*}{ Treatments } & \multicolumn{5}{|c|}{ Growth stages } \\
\hline & 30 DAS & 45 DAS & 60 DAS & 75 DAS & 90 DAS \\
\hline \multicolumn{6}{|c|}{ Effect on variety } \\
\hline $\mathrm{V}_{1}$ & 20.42 & 31.24 & 54.15 & 81.63 & 122.45 \\
\hline $\mathrm{V}_{2}$ & 20.70 & 29.16 & 50.40 & 76.64 & 110.37 \\
\hline $\mathrm{V}_{3}$ & 20.66 & 29.99 & 54.56 & 80.38 & 122.45 \\
\hline $\mathrm{V}_{4}$ & 20.78 & 29.99 & 54.56 & 80.38 & 122.03 \\
\hline $\mathrm{LSD}_{5 \%}$ & 1.99 & 1.99 & 2.30 & 2.22 & 2.12 \\
\hline \multicolumn{6}{|c|}{ Effect on sowing dates } \\
\hline $\mathrm{S}_{1}$ & 20.74 & 30.93 & 53.42 & 79.34 & 120.26 \\
\hline $\mathrm{S}_{2}$ & 20.64 & 29.68 & 53.42 & 80.28 & 119.64 \\
\hline $\mathrm{S}_{3}$ & 20.54 & 29.68 & 53.42 & 79.66 & 118.08 \\
\hline $\mathrm{LSD}_{5 \%}$ & 1.33 & 1.35 & 1.35 & 1.23 & 1.67 \\
\hline \multicolumn{6}{|c|}{ Interaction effect of variety and sowing date } \\
\hline $\mathrm{V}_{1} \mathrm{~S}_{1}$ & 20.12 & 31.24 & 54.98 & 81.22 & 123.70 \\
\hline $\mathrm{V}_{1} \mathrm{~S}_{2}$ & 20.62 & 29.99 & 53.73 & 82.47 & 121.20 \\
\hline $\mathrm{V}_{1} \mathrm{~S}_{3}$ & 20.52 & 32.49 & 53.73 & 81.22 & 122.45 \\
\hline $\mathrm{V}_{2} \mathrm{~S}_{1}$ & 20.97 & 29.99 & 49.98 & 76.22 & 111.21 \\
\hline $\mathrm{V}_{2} \mathrm{~S}_{2}$ & 20.15 & 28.74 & 51.23 & 77.47 & 111.21 \\
\hline $\mathrm{V}_{2} \mathrm{~S}_{3}$ & 20.97 & 28.74 & 49.98 & 76.22 & 108.71 \\
\hline $\mathrm{V}_{3} \mathrm{~S}_{1}$ & 20.87 & 31.24 & 54.98 & 79.97 & 122.45 \\
\hline $\mathrm{V}_{3} \mathrm{~S}_{2}$ & 20.93 & 29.99 & 53.73 & 81.22 & 123.70 \\
\hline $\mathrm{V}_{3} \mathrm{~S}_{3}$ & 20.18 & 28.74 & 54.98 & 79.97 & 121.20 \\
\hline $\mathrm{V}_{4} \mathrm{~S}_{1}$ & 20.99 & 31.24 & 53.73 & 79.97 & 123.70 \\
\hline $\mathrm{V}_{4} \mathrm{~S}_{2}$ & 20.87 & 29.99 & 54.98 & 79.97 & 122.45 \\
\hline $\mathrm{V}_{4} \mathrm{~S}_{3}$ & 20.49 & 28.74 & 54.98 & 81.22 & 119.95 \\
\hline $\operatorname{LSD}_{(0.05)}$ & 0.74 & 0.76 & 0.50 & 0.88 & 0.98 \\
\hline CV (\%) & 1.34 & 1.23 & 1.34 & 1.34 & 1.01 \\
\hline
\end{tabular}

Note: $\left(\mathrm{V}_{1}=\mathrm{PSC}-121, \mathrm{~V}_{2}=\right.$ Yangnuo-7, $\mathrm{V}_{3}=$ Yungnuo-30, $\mathrm{V}_{4}=$ Changnuo-6; $\mathrm{S}_{1}=26^{\text {th }}$ November, $\mathrm{S}_{2}=11$ th December and $\mathrm{S}_{3}=26$ th December

\section{Relationship of dry weight with leaf area}

Linear regression was made to find relations of dry weight with the leaf area irrespective of genotype and sowing dates. It was observed that the leaf area had a moderate effect on the dry weight showing the regression coefficient value of 0.4047 (Fig. 17). As the result of changing sowing date, maize crop receives a different level of radiation as well as thermal temperature and period also vary. Cirilo and Andrade (1994) were found that late sowing of crops decreased their 
growth and development because less amount of solar radiation was captured by the crop during emergence to the silking stage.

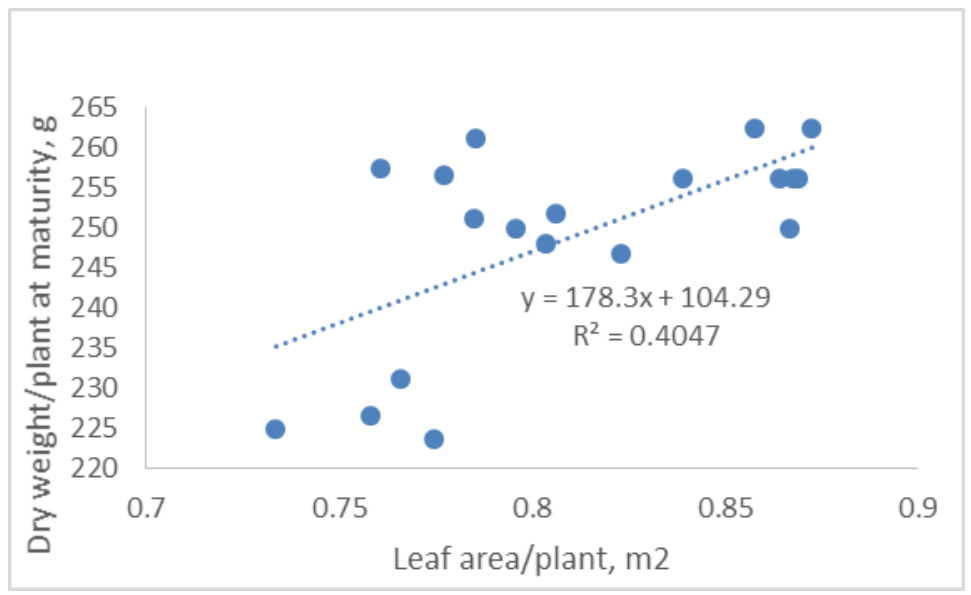

Fig. 17. Relationship of dry weight with leaf area.

\section{Days to Physiological Maturity}

The variety, sowing dates, and their interactions had a significant effect on days to physiological maturity (Figs. 18-20). The highest (134 days) date physiological maturity was found from PSC121 and whereas the lowest (113 days) date from Changnuo-6 of physiological maturity. Crop sown on December 26 recorded the highest (132 days) date of physiological maturity while the lowest (126 days) was observed from November 26 sowing. Among the interaction, s the highest (141 days) date of physiological maturity was observed from the combination of genotype PSC-121 with December 26 sowing. While the lowest (111.00 days) was obtained from the treatment combination of genotype Yungnuo-7 with November 26 sowing. Sangoi (1993) was found hybrid maize planted during earlier sowing date elongated growth period of more than 2 weeks than planted in delayed date.

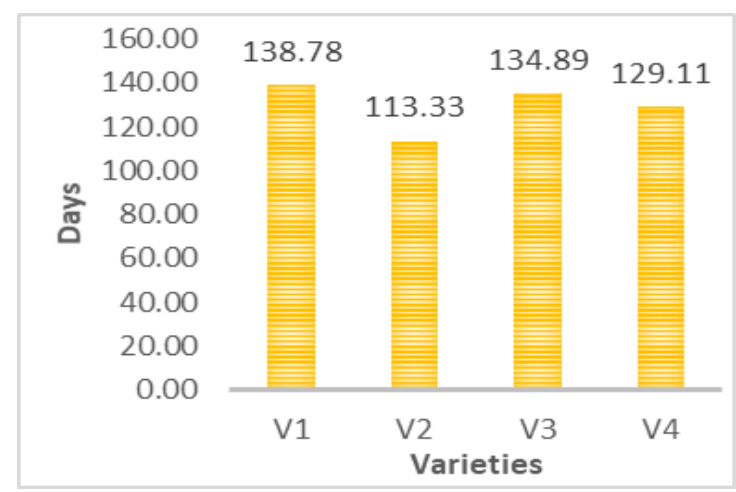

Fig. 18. Days to physiological maturity of different white maize genotypes $\left(\mathrm{V}_{1}=\mathrm{PSC}-121, \quad \mathrm{~V}_{2}=\right.$ Yangnuo-7, $\mathrm{V}_{3}=$ Yungnuo-30, $\mathrm{V}_{4}=$ Changnuo6; $\mathrm{LSD} 5 \%=0.08$ grown in Rabi 2017-2018 season.

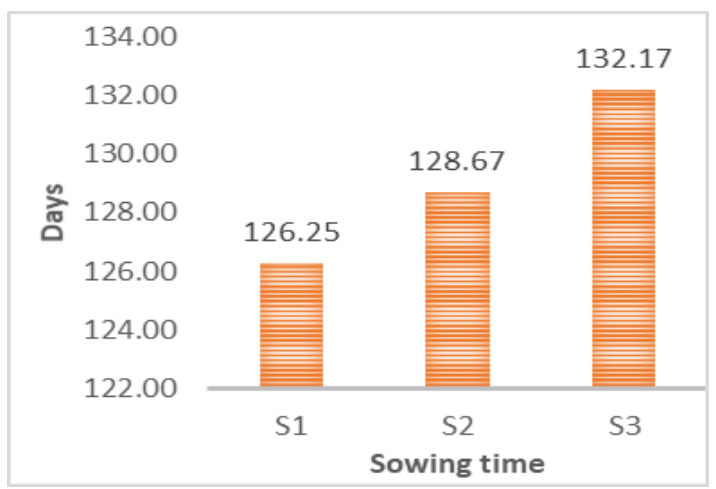

Fig. 19. Days to physiological maturity of white maize as influenced by varying sowing dates $\left(\mathrm{S}_{1}=26\right.$ November, $\mathrm{S}_{2}=11$ th December and $\mathrm{S}_{3}=26$ th December) $(\mathrm{LSD} 5 \%=0.07)$. 


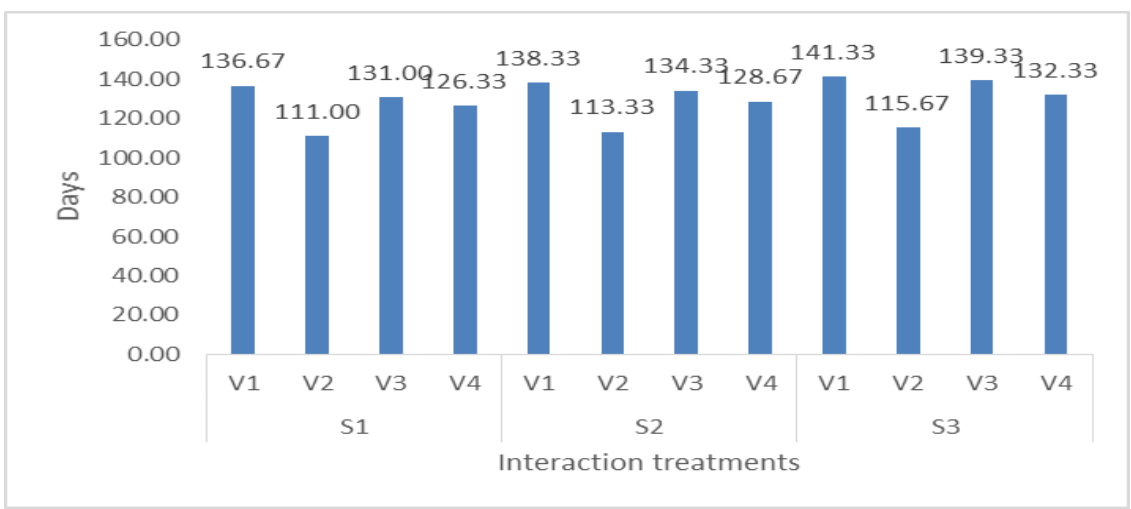

Fig. 20. Days to physiological maturity as influenced by varying sowing dates and genotypes $\left(\mathrm{V}_{1}=\mathrm{PSC}-121, \mathrm{~V}_{2}=\right.$ Yangnuo-7, $\mathrm{V}_{3}=$ Yungnuo-30, $\mathrm{V}_{4}=$ Changnuo-6; $\mathrm{S}_{1}=26$ th November, 11th December and 26th December; LSD5\% $=0.1$ ).

\section{Number of grain row per cob}

The variety, sowing dates, and their interactions had a significant effect on the number of grain rows per cob (Table 3).

Table 3. Yield attributes of white maize genotypes under varying sowing dates during Rabi 2017-18

\begin{tabular}{|c|c|c|c|c|}
\hline Treatments & $\begin{array}{l}\text { Number of grain } \\
\text { row per cob }\end{array}$ & $\begin{array}{l}\text { Number of grains } \\
\text { per row on a cob }\end{array}$ & $\begin{array}{c}\text { Number of grains per } \\
\text { cob }\end{array}$ & $\begin{array}{c}\text { 100- grain } \\
\text { weight }\end{array}$ \\
\hline \multicolumn{5}{|c|}{ Effect on variety } \\
\hline $\mathrm{V}_{1}$ & 13.67 & 22.11 & 301.84 & 31.16 \\
\hline $\mathrm{V}_{2}$ & 11.44 & 16.07 & 183.72 & 26.25 \\
\hline$V_{3}$ & 13.50 & 20.94 & 282.55 & 31.38 \\
\hline $\mathrm{V}_{4}$ & 13.56 & 20.24 & 274.50 & 32.80 \\
\hline $\operatorname{LSD}_{(0.05)}$ & 0.68 & 0.87 & 0.96 & 1.00 \\
\hline \multicolumn{5}{|c|}{ Effect on sowing dates } \\
\hline $\mathrm{S}_{1}$ & 13.08 & 21.11 & 278.75 & 32.38 \\
\hline $\mathrm{S}_{2}$ & 12.83 & 20.02 & 258.45 & 30.01 \\
\hline $\mathrm{S}_{3}$ & 13.67 & 18.34 & 244.75 & 28.80 \\
\hline $\mathrm{LSD}_{(0.05)}$ & 0.58 & 0.75 & 0.83 & 0.87 \\
\hline \multicolumn{5}{|c|}{ Interaction effect of variety and sowing date } \\
\hline $\mathrm{V}_{1} \mathrm{~S}_{1}$ & 14.00 & 23.10 & 323.40 & 33.02 \\
\hline $\mathrm{V}_{1} \mathrm{~S}_{2}$ & 13.00 & 23.11 & 300.43 & 30.43 \\
\hline $\mathrm{V}_{1} \mathrm{~S}_{3}$ & 14.00 & 20.12 & 281.68 & 30.04 \\
\hline $\mathrm{V}_{2} \mathrm{~S}_{1}$ & 11.33 & 16.80 & 190.34 & 28.98 \\
\hline $\mathrm{V}_{2} \mathrm{~S}_{2}$ & 11.33 & 16.54 & 187.40 & 26.50 \\
\hline $\mathrm{V}_{2} \mathrm{~S}_{3}$ & 11.67 & 14.86 & 173.42 & 23.27 \\
\hline $\mathrm{V}_{3} \mathrm{~S}_{1}$ & 13.33 & 22.40 & 298.59 & 33.43 \\
\hline $\mathrm{V}_{3} \mathrm{~S}_{2}$ & 13.67 & 20.76 & 283.79 & 30.57 \\
\hline $\mathrm{V}_{3} \mathrm{~S}_{3}$ & 13.50 & 19.65 & 265.28 & 30.13 \\
\hline $\mathrm{V}_{4} \mathrm{~S}_{1}$ & 13.67 & 22.14 & 302.65 & 34.10 \\
\hline $\mathrm{V}_{4} \mathrm{~S}_{2}$ & 13.33 & 19.67 & 262.20 & 32.54 \\
\hline $\mathrm{V}_{4} \mathrm{~S}_{3}$ & 13.67 & 18.92 & 258.64 & 31.76 \\
\hline $\mathrm{LSD}_{(0.05)}$ & 1.17 & 1.51 & 1.66 & 1.74 \\
\hline CV $(\%)$ & 5.41 & 1.38 & 1.75 & 3.38 \\
\hline
\end{tabular}

Note: $\left(\mathrm{V}_{1}=\mathrm{PSC}-121, \mathrm{~V}_{2}=\right.$ Yangnuo-7, $\mathrm{V}_{3}=$ Yungnuo-30, $\mathrm{V}_{4}=$ Changnuo-6; $\mathrm{S}_{1}=26^{\text {th }}$ November, $\mathrm{S}_{2}=11$ th December and $S_{3}=26$ th December 
The highest (13.67) number of rows was found from the genotype PSC-121 whereas the lowest (11.44) number of rows from Yungnuo-7. Crop sown on December 26 recorded the highest (13.67) number of row while lowest (12.83) number of rows from December 11 sowing. Among the interaction, the highest number of rows (14) was observed from the combination of PSC121 genotype and December 26 while the lowest number of rows (11.33) from genotype Yungnuo-7 with November 26 sowing.

\section{Number of grains per row on a cob}

The variety, sowing dates, and their interactions had a significant effect on the number of grains per row on a cob (Table 3). The highest (22.11) number of grains per row was found from PSC121 and whereas the lowest (16.07) from Yungnuo-7. Crop sown on November 26 recorded the highest number of grains per row (21.11) while the lowest (18.38) number of grains per row from December 26 sowing. Among the interaction effect, the highest number of grains per row (23.11) was observed from the combination of PSC-121 genotype with December 11 sowing while the lowest (14.86) from the treatment combination of genotype Yungnuo-7y with December 26 sowing.

\section{Number of grains per cob}

The variety, sowing dates, and their interactions had a significant effect on the number of grains per cob (Table 3). The highest (301.84) number of grains per cob was found from genotype, PSC-121 and whereas the lowest (183.72) from Yungnuo-7. Crop sown on November 26 recorded the highest (278.75) number of grains per while the lowest number of grains per cob (244.75) from December 26 sowing. Among the interaction effect, the highest number of grains per cob (323.4) was observed from the combination of genotype PSC-121 with November 26 sowing. While the lowest number of grains of cob (173.42) was obtained from genotype Yungnuo-7 with December 26 sowing. Grain number per cob, as well as flower distribution, had been adversely affected by the delay in sowing dates (Otegui and Melon, 1997).

\section{0- grain weight}

The variety, sowing dates, and their interactions had a significant effect on 100-seed weight (Table 3). The highest 100-seed weight (32.8 g) was found from Changnuo-6 and whereas the lowest $(26.25 \mathrm{~g})$ from genotype Yungnuo-7 (26.25 g). Crop sown on November 26 was recorded the highest $(32.38 \mathrm{~g})$ number of grains per cob while the lowest weight $(28.80 \mathrm{~g})$ from December 26 sowing. Among the interaction, the highest weight $(34.10 \mathrm{~g})$ was observed from the combination of Changnuo- 6 genotype with November 26 sowing. While the lowest weight $(23.27 \mathrm{~g})$ was obtained from the treatment combination of genotype (Yungnuo-7) with December 26 sowing. Killi and Altanbay (2005) also observed that seed weight was significantly affected by the sowing dates.

\section{Grain yield}

Proper selection of sowing dates can optimize maize yield. The variety, sowing dates, and their interactions had a significant effect on grain yield per hectare (Figs. 21-23). The highest (11.48 $t$ $\left.\mathrm{ha}^{-1}\right)$ grain yield was found from PSC-121 and whereas the lowest $\left(7.87 \mathrm{t} \mathrm{ha}^{-1}\right)$ from genotype (Changnuo-6). Crop sown on November 26 recorded the highest (10.14 t ha-1) grain yield while lowest weight $\left(9.97 \mathrm{t} \mathrm{ha}^{-1}\right)$ from December 26 sowing. Among the interaction effect, the highest (11.65 $\mathrm{t} \mathrm{ha}^{-1}$ ) grain yield was observed from the combination of PSC-121 genotype with November 26 sowing while the lowest $\left(7.81 \mathrm{t} \mathrm{ha}^{-1}\right)$ from the treatment combination genotype (Yungnuo-7) with December 26 sowing. Considerable yield declined as a result of sowing too 
late as reported in maize (Meza et al., 2008). Maize yield response to sowing date is very similar in different years and locations attributing yield benefits to early sowing (Good et al., 2015; Shrestha et al., 2016).

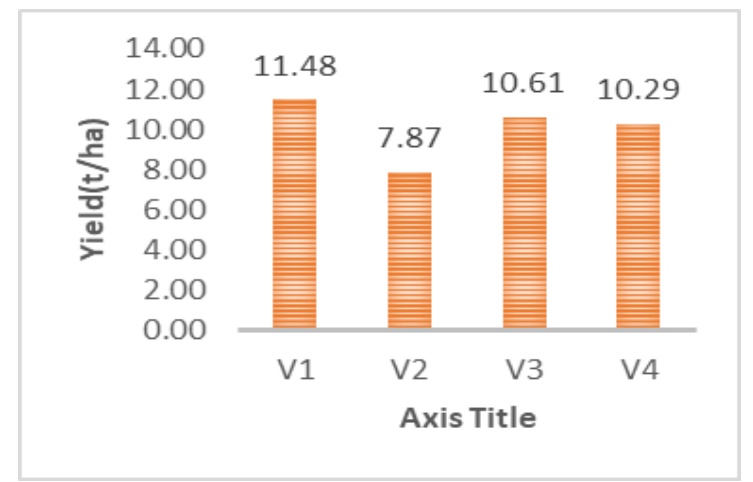

Fig. 21. Per hectare seed yield of different white maize genotypes $\left(\mathrm{V}_{1}=\mathrm{PSC}\right.$ 121, $\quad \mathrm{V}_{2}=$ Yangnuo-7, $\quad \mathrm{V}_{3}=$ Yungnuo-30, $\quad \mathrm{V}_{4}=$ Changnuo-6; LSD $5 \%=0.1$.

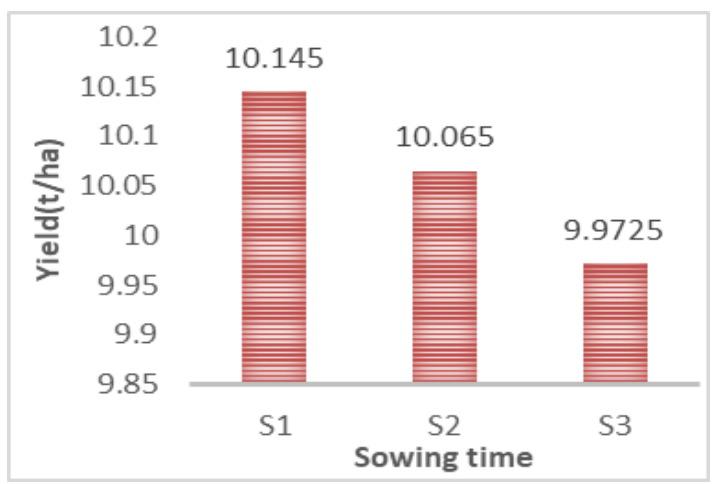

Fig. 22. Per hectare seed yield of white maize as influenced by varying sowing dates $\left(\mathrm{S}_{1}=26 \quad\right.$ November, $\mathrm{S}_{2}=11$ th December, and $\mathrm{S}_{3}=26$ th December) $(\mathrm{LSD} 5 \%=0.08$.

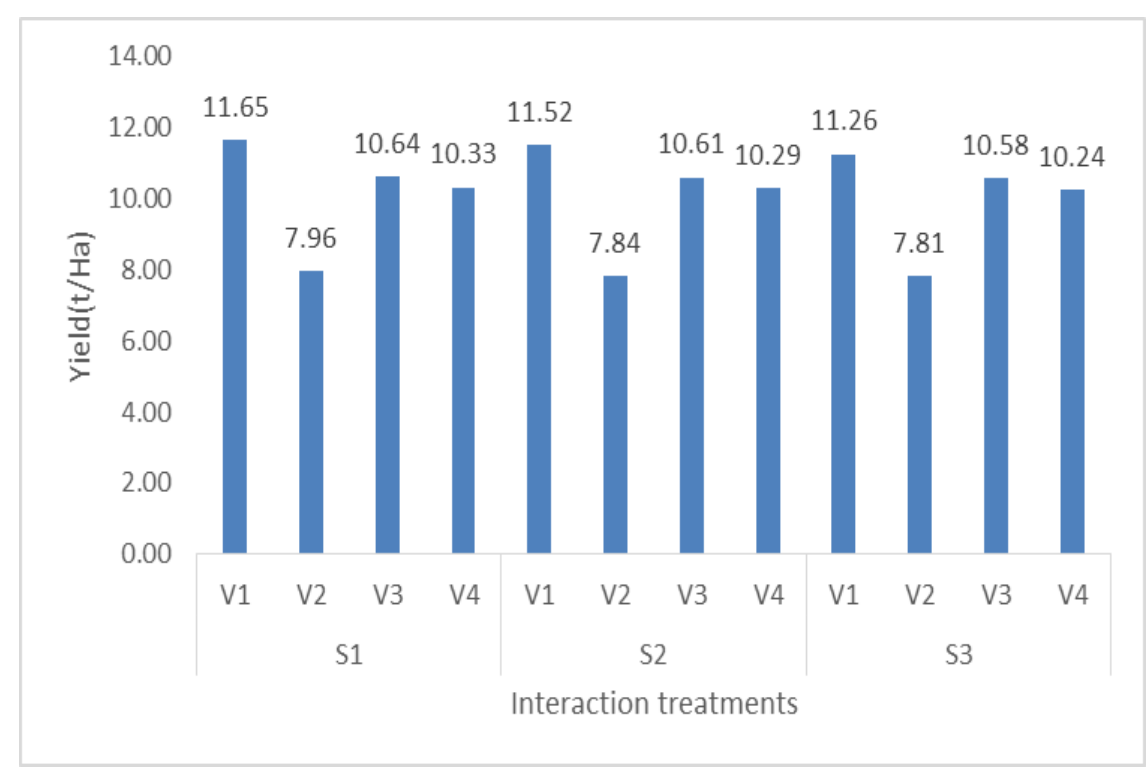

Fig. 23. Per hectare seed yield of white maize as influenced by varying sowing dates and genotypes $\left(\mathrm{V}_{1}=\mathrm{PSC}-121, \mathrm{~V}_{2}=\right.$ Yangnuo-7, $\mathrm{V}_{3}=$ Yungnuo-30, $\mathrm{V}_{4}=$ Changnuo- 6 ; $\mathrm{S}_{1}=26$ th November, $\mathrm{S}_{2}=11$ th December and $\mathrm{S}_{3}=26$ th December; LSD5\% $=0.17$.

\section{Conclusion}

From the present study it may be concluded that the genotype PSC-121 gave the highest yield and yield attributes when sown on November 26. This information may be useful for maize growers and researchers. 


\section{References}

Ahmmed, T., M.J. Ullah, M.A. Mannan and M.S. Akter. 2020. Performance of white maize under different spacing and integrated fertilizer management. Asian Plant Res. J. 6(2): 23-32.

Ali, W., M. Ali, Z. Ahmad, J. Iqbal, S. Anwar, M.H. Khan and A. Kamal. 2018. Influence of sowing dates on varying maize (Zea mays L.) varieties grown under agro-climatic condition of Peshawar, Pakistan. Eur. J. Exp. Biol. 8(6): 36.

Anapalli, S., S.L. Ma, D.C. Nielsen, M.F. Vigil and L.R. Ahuja. 2005. Simulating planting date effects on corn production using RZWQM and CERES Maize models. Agron. J. 17: 58-71.

BARI (Bangladesh Agricultural Research Institute). 2016. BARI Annual Report 2015-16. pp.27-38.

Cirilo, A.G. and F.H. Andrade. 1994. Sowing date and maize productivity: I. Crop growth and dry matter partitioning. Crop Sci. 34: 1039-1043.

Good, D., J. Newton and S. Irwin. 2015. Early Planting and 2015 Corn Yield Prospects: How much of an increase? Farmdoc Daily, p.5.

Khanam, M., M.S. Islam, M.H. Ali, I.F. Chowdhury and S.M. Masum. 2016. Performance of soybean under different levels of phosphorus and potassium. Bangladesh Agron. J. 19(1): 99-108.

Killi, F. and S.G. Altunbay. 2005. Seed yield, oil content and yield components of confection and oil seed sunflower cultivars (Helianthus annuus L.) planted on different dates. Int. J. Agric. Biol.7: 21-24.

Koca, Y.O. and O. Canavar. 2014. The effect of sowing date on yield and yield components and seed quality of corn (Zea mays L.). Scientific Papers. Series A. Agron. LVII: 227-231.

Liaqat, W., M. Akmal and J. Ali. 2018. Planting dates effect on production of high yielding maize varieties. Sarhad J. Agri. 34(1): 102-113.

Malvar, R.A., P. Revilla, J. Moreno-González, A. Butrón, J. Sotelo and A. Ordás. 2008. White maize: genetics of quality and agronomic performance. Crop Sci. 48: 1373-1381.

Meza, F.J., D. Silva and H. Vigil. 2008. Climate change impacts on irrigated maize in Mediterranean climates: Evolution of double cropping as an adaptation alternative. Agric. Syst. 98: 21-30.

Otegui, M.E. and S. Melon. 1997. Kernel set and flower synchrony within the ear of maize: I. Sowing date effects. Crop Sci. 37: 441-447.

Ramankutty, N., J.A Foley, J. Norman and K. McSweeney. 2002. The global distribution of cultivable lands: Current patterns and sensitivity to possible climate change. Global Ecol. Biogeogr. 13: 377-392.

Sangoi, L. 1993. Aptidao dos campos de langes (SC) para producao de milho em diferentes epocas de semeadura. Pesquira Agropecuaria Brasileira. Brasilia. 28: 51-63

Shrestha, U., L.P. Amgain, T.B. Karki, K.R. Dahal and J. Shrestha. 2016. Effect of sowing dates and maize cultivars in growth and yield of maize along with their agro-climatic indices in Nawalparasi, Nepal. J. AgriSearch. 3(1): 57-62.

Ullah, M.J., M.M. Islam, K. Fatima, M.S. Mahmud, J. Rahman and S. Akhter. 2017. Comparing modern varieties of white maize with local races: ear characters. J. Expt. Biosci. 8(2): 49-58.

Varma, V.S., K.K. Durga and P. Neelima. 2014. Effect of planting date on maize grain yield and quality: a review. Review Plant Studi.1(2): 26-38.

Williams II, M.M. 2008. Sweet corn growth and yield responses to planting dates of the North Central United States. Hort. Sci. 43: 1775-1779. 